\title{
CHANGES IN TIFTON 85 BERMUDAGRASS HAY STORAGE IN THE FIELD OR UNDER SHED
}

\author{
ALTERAÇÕES NO FENO DE CAMPIM TIFTON 85 ARMAZENADO À CAMPO \\ OU GALPÃO COBERTO
}

\author{
Neres, M.A. ${ }^{*}$; Castagnara, D.D. ${ }^{1}$; Mufatto, L.M. ${ }^{1}$; Fernandes, T. ${ }^{\text {; }}$ Hunoff, C.A. ${ }^{1}$; \\ Wobeto, J.R. ${ }^{1}$ and Nath, C.D. ${ }^{1}$
}

\author{
${ }^{1}$ Agricultural Science Center. UNIOESTE, PR. Marechal Cândido Rondon Center, PR. Paraná. Brazil. \\ *marcela.neres@unioeste.br
}

\section{AdDITIONAL KEYWORDS}

Protein. Forage conservation. Hay heating. Penicillium.

\section{SUMMARY}

The variations of chemical composition, and occurrence of fungi in Tifton 85 bermudagrass hay stored in the field or under shed for 30 days were evaluated. The desing used was completely randomized design with plots subdivided by time with two storage systems, four assessment periods. After 30 days, crude protein was reduced and acid detergent insoluble protein (ADIP) contents increased, with low occurrence of fungi Aspergillus, Rizophus, and Cladosporium and high occurrence of Geotrichium, Phoma, PeniciIlium, and Diploccocum.

\section{RESUMO}

Avaliou-se as variações de composição química e ocorrência de fungos no feno de Tifton 85 armazenado à campo ou em galpão por 30 dias. $\mathrm{O}$ delineamento experimental foi inteiramente casualizado em parcelas subdivididas no tempo, com dois sistemas de armazenamento e quatro períodos de avaliação. Verificou-se que, dentro de um curto período de tempo (30 dias), houve redução da PB e aumento da PIDA com baixa ocorrência de fungos Aspergillus, Rizophus e Cladosporium e alta ocorrência de Geotrichium, Phoma, Penicillium e Diploccocum.

\section{INTRODUCTION}

In animal production systems, the quality of food is crucial in achieving pro-

\section{PALAVRAS CHAVE ADICIONAIS}

Aquecimento do feno. Conservação de forragem. Penicillium. Proteína.

duction efficiency (Jobim et al., 2007) with highlighting the use of conserved forage as hay. However, the nutritive value of hay can be altered by production and storage procedures with influence on the chemical composition, intake, forage digestibility (Jobim et al., 2007), and sanitary quality.

The goal of this study was to investigate changes in dry matter content, chemical composition, and fungal growth in Tifton 85 hay subjected to two different storage environments.

\section{MATERIALS AND METHODS}

The experiment was conducted in a field of Cynodon 'Tifton' 85, located in 24 $33^{\circ} 40^{\prime \prime}$ south latitude, $54^{\circ} 04^{\prime} 12^{\prime \prime}$ west longitude, in oxisol.

During Tifton 85 regrowth (January and February), cutting and afterward (15 March), dehydration conditions were favourable at $24.7^{\circ} \mathrm{C}$ temperature, $65 \%$ relative humidity, and $18645 \mathrm{~kJ} \mathrm{~m}^{-2}$ radiation, with $2 \mathrm{~mm} \mathrm{day}^{-1}$ average rainfall during storage.

It was adopted a randomized design due area uniformity with DM production of 4899 $\mathrm{kg} \mathrm{ha}^{-1}$; leaf:stem ratio 1.71 ; plant height 60 $\mathrm{cm}$; and stem diameter $1.32 \mathrm{~mm}$. 
In 1 March, when Tifton 85 bermudagrass with 38 days of regrowth was cut with knives by a tractor mower to a height of $5 \mathrm{~cm}$. To investigate dehydration, the experimental design was completely randomized with nine sampling times of dehydration $(0,8,23,32$, $47,56,71,80$, and $95 \mathrm{~h}$ after cutting) and five replicates. The samples were dried at $55^{\circ} \mathrm{C}$ to determine DM.

The hay chemical composition was studied via a complete randomized design in plots subdivided by time $(2 \times 4)$, such that plots were allocated to two storage environments (in the field under transparent plastic canvas and in a well-ventilated shed) and four periods: cutting, baling, 15, and 30 days of hay storage. The hay was baled after 95 hours of dehydration in rectangular bales with an average weight of $5.44 \mathrm{~kg}$. When stored in the field, the hay was under plastic canvas placed directly under the soil, making two stacks of 12 bales each, approximately $2 \mathrm{~m}$ wide by $2 \mathrm{~m}$ high in size.

For shed storage, hay was housed in a ventilated brick shed covered with clay tiles, with brick flooring and a ceiling height of 5 $\mathrm{m}$. Hay was placed inside the shed in two stacks of 12 bales each $10 \mathrm{~cm}$ above the floor on wooden pallets. For both hay stored in the field and in the shed, the first stack was dismantled and the bales opened for sampling after 15 days of storage, and the second stack was opened after 30 days. At the time of sampling, samples were collected to determine DM contents, subsequent chemical analyses, and presence of fungi.

The DM was determined from samples dried at $55^{\circ} \mathrm{C}$ for $72 \mathrm{~h}$, with later determination of crude protein $(\mathrm{CP})$, neutral detergent fiber (NDF), acid detergent fiber (ADF), neutral detergent insoluble protein (NDIP, $\mathrm{g} \mathrm{kg}^{-1}$ $\mathrm{CP}$ ), acid detergent insoluble protein (ADIP, $\mathrm{g} \mathrm{kg}^{-1} \mathrm{CP}$ ), lignin hemicellulose, and cellulose (Van Soest, 1994).

Fungi (CFU-colony forming units) were isolated by the induction of mycelium growth in a PDA culture medium, with identification through reproductive structures (Samson et al., 1995) and result expressed as $\log$ $\mathrm{CFU} \mathrm{g}^{-1}$.

The DM data during dehydration were subjected to regression analysis to obtain a dehydration curve. The DM data after storage and chemical composition were subjected to analysis of variance, and means were compared by the Tukey test at $5 \%$ probability. The occurrence of fungi genera was assessed by descriptive analyses.

\section{RESULTSANDDISCUSSION}

During dehydration, the DM contents adjusted the third-degree polynomial regression model $(\mathrm{Y}=282,24+15,86 \mathrm{x}-$ $\left.0,20 x^{2}+0,0009 x^{3} ; R^{2}=0,86 ; C V(\%)=12,16\right)$ due to a sharp drop that occurred in the DM content sampling conducted at 8:00 of the second day of dehydration. This decrease in DM was due to the accumulation of dew overnight and has been observed in other studies under similar conditions (Neres et al., 2010).

At the time of baling, there was no difference in DM ( $\mathrm{p}>0.05)$, with an average of $887.9 \mathrm{gkg}^{-1}$. The differences in dry matter arose after 15 days of storage but were never significant ( $p>0.05)$, with a tendency to increase in the hay stored in the field. After 30 days of storage, the dry hay stored in the field had lower moisture $(\mathrm{p}<0.05)$ compared to hay stored in the shed (table I).

Changes in the DM affected the chemical composition of the hay because CP concentration decreased during dehydration and after storage (table I). Decreases in the CP content of Tifton 85 bermudagrass hay observed after baling compared to immediately after cutting are due to intracellular biochemical changes, such as respiration and oxidation, which are inevitable during drying (Jobim et al., 2007). However, greater hay exposure to environmental conditions provided by storage in the field did not favour the maintenance of the respiratory processes after baling, leading to similar levels between $\mathrm{CP}$ in the 


\section{CHANGES IN TIFTON 85 BERMUDAGRASS HAY STORAGE FIELD OR UNDER SHED}

hay stored in the field and the shed.

Concentrations of NDF and hemicellulose were affected by storage time and observed to decrease after cutting for baling and after storage, while the ADF was not altered by the factors studied (table I). These reductions were consistent since hemi- cellulose, cellulose, and lignin are NDF components, which hydrolysis of ester-type covalent bonds between lignin and structural carbohydrates causes the solubilisation of hemicellulose and phenolic compounds and decreases NDF (Van Soest, 1994).

The reduction in hemicellulose in fibrous

Table I. Chemical composition of Tifton 85 bermudagrass hay at cutting, baling, and after 15 and 30 days of storage in the field or under shed. (Composição química do feno de Tifton 85 no corte, enfardamento e após 15 e 30 dias de armazenamento á campo ou em galpão).

\begin{tabular}{|c|c|c|c|c|c|c|c|c|c|}
\hline \multirow[b]{2}{*}{ Time } & \multicolumn{4}{|c|}{ Dry matter content $\left(\mathrm{g} \mathrm{kg}^{-1}\right)$} & \multicolumn{2}{|c|}{$\mathrm{CP}\left(\mathrm{g} \mathrm{kg}^{-1}\right)$} & \multicolumn{3}{|c|}{$\operatorname{NDF}\left(\mathrm{g} \mathrm{kg}^{-1}\right)$} \\
\hline & Shed & Field & Mean & Field & Shed & Mean & Field & Shed & Mean \\
\hline Cutting & $280.47^{\mathrm{Ab}}$ & $284.68^{\mathrm{AC}}$ & 282.58 & 108.97 & 108.58 & $108,77^{a}$ & 787.9 & 786.8 & $787.3^{\mathrm{a}}$ \\
\hline Baling & $887.88^{\mathrm{Aa}}$ & $887.88^{\mathrm{Aa}}$ & 887.88 & 94.98 & 95.18 & $95.08^{b}$ & 786.2 & 782.7 & $784.4^{\mathrm{ab}}$ \\
\hline 15 days stored & $901.35^{\mathrm{Aa}}$ & $922.34^{\mathrm{Aa}}$ & 911.85 & 89.31 & 92.06 & $90.68^{\mathrm{bc}}$ & 762.4 & 772.3 & $767.3^{\mathrm{bc}}$ \\
\hline 30 days stored & $839.48^{\mathrm{Ab}}$ & $739.91^{\mathrm{Bb}}$ & 789.70 & 86.48 & 89.59 & $88.03^{c}$ & 746.5 & 757.9 & $752.2^{c}$ \\
\hline Mean & 727.30 & 708.70 & & $94.93^{\mathrm{A}}$ & $96.35^{\mathrm{A}}$ & & $770.7^{\mathrm{A}}$ & $774.9^{\mathrm{A}}$ & \\
\hline CV1 (\%) & & 3.89 & & & 1.98 & & & 1.44 & \\
\hline \multirow[t]{2}{*}{ CV2 (\%) } & & 3.81 & & & 4.79 & & & 2.08 & \\
\hline & \multicolumn{3}{|c|}{$A D F\left(g ~ k g^{-1}\right)^{n s}$} & \multicolumn{3}{|c|}{ Hemicellulose $\left(\mathrm{g} \mathrm{kg}^{-1}\right)$} & \multicolumn{3}{|c|}{ Lignin $\left(\mathrm{g} \mathrm{kg}^{-1}\right)$} \\
\hline Time & Shed & Field & Mean & Field & Shed & Mean & Field & Shed & Mean \\
\hline Cutting & 402.7 & 403.7 & 403.2 & 380.2 & 380.9 & $380.5^{\mathrm{a}}$ & 53.3 & 52.1 & $52.7^{\mathrm{b}}$ \\
\hline Baling & 398.1 & 398.9 & 398.5 & 370.5 & 372.5 & $371.5^{\mathrm{ab}}$ & 94.3 & 93.7 & $94.0^{\mathrm{a}}$ \\
\hline 15 days stored & 400.3 & 396.6 & 398.4 & 362.0 & 375.7 & $368.9^{a b}$ & 104.6 & 93.7 & $99.1^{a}$ \\
\hline 30 days stored & 389.7 & 396.4 & 393.0 & 356.9 & 361.6 & $359.2^{b}$ & 110.2 & 102.3 & $106.3^{a}$ \\
\hline Mean & 395.4 & 398.9 & & $367.4^{\mathrm{A}}$ & $372.7^{\mathrm{A}}$ & & $90.6^{A}$ & $85.5^{\mathrm{A}}$ & \\
\hline CV1 (\%) & & 2.18 & & & 2.34 & & & 7.66 & \\
\hline \multirow[t]{2}{*}{ CV2 (\%) } & & 4.11 & & & 4.18 & & & 14.38 & \\
\hline & \multicolumn{3}{|c|}{ Cellulose $\left(\mathrm{g} \mathrm{kg}^{-1}\right)$} & \multicolumn{3}{|c|}{$\operatorname{NDIP}\left(\mathrm{g} \mathrm{kg}^{-1} \mathrm{CP}\right)$} & \multicolumn{3}{|c|}{ ADIP $\left(\mathrm{g} \mathrm{kg}^{-1} \mathrm{CP}\right)^{\mathrm{ns}}$} \\
\hline Time & Shed & Field & Mean & Field & Shed & Mean & Field & Shed & Mean \\
\hline Cutting & 369.3 & 368.1 & $368.7^{b}$ & 624.5 & 627.3 & $625.9^{\mathrm{a}}$ & 312.0 & 313.8 & $312.9^{b}$ \\
\hline Baling & 494.7 & 491.9 & $493.3^{a}$ & 580.0 & 575.6 & $577.8^{\mathrm{ab}}$ & 333.8 & 335.3 & $334.6^{b}$ \\
\hline 15 days stored & 502.4 & 492.5 & $497.4^{\mathrm{a}}$ & 568.9 & 554.9 & $561.9^{b}$ & 355.2 & 347.0 & $351.1^{\mathrm{ab}}$ \\
\hline 30 days stored & 505.0 & 509.8 & $507.4^{\mathrm{a}}$ & 546.4 & 523.1 & $534.7^{b}$ & 401.9 & 381.9 & $391.9^{a}$ \\
\hline Mean & $467.8^{A}$ & $465.6^{\mathrm{A}}$ & & 579.9 & 570.2 & & $350.7^{A}$ & $344.5^{\mathrm{A}}$ & \\
\hline CV1 (\%) & & 4.36 & & & 11.94 & & & 7.66 & \\
\hline CV2 (\%) & & 7.39 & & & 8.03 & & & 10.42 & \\
\hline
\end{tabular}

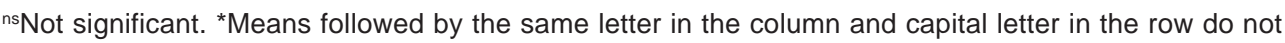
differ by the Tukey test (5\%). CV1 (\%): coefficient of variation of the plot; CV2 (\%): coefficient of variation of the subplot.

$\mathrm{NDIP}=$ neutral detergent insoluble protein; $\mathrm{ADIP}=$ acid detergent insoluble protein. 
materials may be caused by the action of fungi, which use these materials as a substrate for fermentation (Schmidt et al., 2003). The lignin and cellulose contents were lower $(\mathrm{p}<0.05)$ at time of cutting compared to other stages of production and hay storage (table I). There was no effect of the storage system $(p>0.05)$. Changes in the fibrous components are due to DM losses that naturally occur with hay storage. With the loss of DM, there is a reduction in nonstructural carbohydrates, while the fibrous components of forage are maintained; due to DM losses, these concentrations are increased.

An effect of storage time was observed on the concentrations of NDIP and ADIP but with opposite behaviour (table I). While the NDIP concentration decreased with cutting, baling, and storage of Tifton 85 bermudagrass hay, the ADIP concentration increased. These results may be associated with reduced hemicellulose and maintenance of the FDA components (cellulose and lignin). Since the ADIP is the nitrogen adhered to cellulose and lignin (Van Soest, 1994), reduced hemicellulose due to DM losses and maintenance of these components led to the increased final concentration of this component in the hay.

The increased hay ADIP concentrations could not be explained by heating, as temperatures remained near room temperature after baling. This is further supported by hay being baled with an appropriate

\section{REFERENCES}

Jobim, C.C.; Nussio, L.G.; Reis, R.A. e Schmidt, P. 2007. Avanços metodológicos na avaliação da qualidade da forragem conservada. Rev Bras Zootecn, 36: 101-119.

Neres, M.A.; Castagnara, D.D.; Mesquita, E.E.; Zambom, M.A.; Souza, L.C.; Oliveira, P.S. and Jobim, C.C. 2010. Production of alfalfa hay under different drying methods. Rev Bras Zootecn, 39: 1676-1683.

Samson, R.A.; Hokstra, E.S. and Frisvad, J.C. concentration of DM (i.e., more than $850 \mathrm{~g}$ $\left.\mathrm{kg}^{-1}\right)$. Concentrations of cellulose and lignin increased in cut hay after 30 days of storage; therefore, further studies are necessary to evaluate the chemical composition and hay digestibility with longer periods of storage. In this way, the hay should not be stored for long periods and should be immediately sold or supplied to animals.

Among fungi found in Tifton 85 bermudagrass hay, greater occurrence after 30 days of storage occurred for Colleotrichum (1.77 log CFU g ${ }^{-1}$ ), Geotrichium (0.92 log CFU g ${ }^{-1}$ ), Diplococcium (1.29 $\log \mathrm{CFU} \mathrm{g}^{-1}$ ), Phoma (1.27 $\log \mathrm{CFU} \mathrm{g}^{-1}$ ), and Penicillium (0.90 log $\left.\mathrm{CFU} \mathrm{g}^{-1}\right)$. Fungi of the genera Penicillium and Aspergillus are common in storage, and there was higher incidence of Penicillium in hay after 30 days of storage. The same occurred with fungi of the genera Phoma and Colleotrichium. The genera Fusarium (fungi typical in the field), Rizophus, and Cladosporium, considered saprophytic, had low occurrence $(0.27 \mathrm{log}$ $\mathrm{CFU} \mathrm{g}^{-1}$ ).

\section{CONCLUSIONS}

Storage in the field or shed for 30 days can cause changes in the chemical composition of Tifton 85 bermudagrass hay. If the hay remains stored, there can be changes in $\mathrm{CP}$ and increases of lignin and ADIP. The genera Penicillium, Colleotrichum, Geotrichium, Diplococcium, and Phoma increased with time of storage

1995. Introduction to food-borne fungi. $4^{\text {th }}$ ed Centraal Bureau voor Schimmelcultures. Baarm. Netherlands. 322 pp.

Schmidt, P.; Wechsler, F.S.; Vargas Júnior, F.M. and Rossi, P. 2003. Valor nutritivo do feno de braquiária amonizado com uréia ou inoculado com Pleurotus ostreatus. Rev Bras Zootecn, 32: 1866-1871.

Van Soest, P.J. 1994. Nutritional ecology of the ruminant. Comstock Pub. Associates. Ithaca. 476 pp. 